\title{
Aanschafprijzen en vervangingswaarden
}

Korte tijd geleden heeft De Jong in dit maandblad de mogelijke dubbeltellingen in calculaties o.b.v. vervangingswaarden opnieuw aan de orde gesteld ${ }^{1}$. Hoewel zijn zienswijze op een aantal punten overeenstemt met mijn opvattingen, die o.a. in 1981 in dit maandblad zijn uiteengezet ${ }^{2}$, acht ik zijn behandeling van de onderhavige problematiek niet geheel bevredigend. Teneinde verdere misverstanden te helpen voorkomen, meen ook ik nog eens op deze materie te moeten terugkomen.

Mijn voornaamste bezwaar tegen De Jong's betoog is, dat hij onvoldoende oog heeft voor de nadelen die aan calculaties o.b.v. aanschafprijzen zijn verbonden. Weliswaar wijst hij calculatie o.b.v. vervangingswaarden niet van de hand, maar hij is toch van mening dat een onderneming die naar handhaving van haar kapitaalgoederencomplex en financiële structuur streeft, bij specifieke prijswijzigingen 'kan volstaan met het nominalistische, historische kostprijssysteem' ${ }^{3}$ terwijl ook bij inflatoire prijswijzigingen 'de nominalistische (historische kostprijs) calculatie adequaat' zou zijn ${ }^{4}$. Zijn eindconclusie is dan ook, dat men in financiële calculaties wel van vervangingswaarden uit kan gaan, maar: 'Wellicht is het toch duidelijker en zeker eenvoudiger alle kosten op nominalistische basis te calculeren!'

Zie ik het goed, dan moet De Jong's visie worden verklaard uit het feit dat hij slechts één soort eenvoudige voorbeelden beschouwt. Hij richt de aandacht namelijk uitsluitend op voorraden niet-duurzame goederen, die op één tijdstip geheel worden verkocht en vervangen. Inderdaad kan een kostencalculatie o.b.v. aanschafprijzen onder deze omstandigheden tot dezelfde uitkomsten leiden als een kostencalculatie o.b.v. vervangingswaarden. Dit geldt echter niet in het algemeen: Normaliter levert een calculatie o.b.v. uitgaafprijzen onbruikbare uitkomsten op en verschaft een calculatie o.b.v. vervangingswaarden zinvolle informatie.

Eén en ander wordt hieronder verder toegelicht. Daarbij wordt eerst enkele ogenblikken stilgestaan bij de ook door De Jong besproken aan- en verkoop van niet-duurzame goederen. Vervolgens worden de niet door hem aangeroerde calculaties omtrent duurzame produktiemiddelen in de beschouwingen betrokken. De eindconclusie kan daarna kort worden geformuleerd.

Binnen elk van de volgende twee paragrafen wordt onderscheid gemaakt tussen (a) de kostencalculatie ter beoordeling van verkoopprijzen van eind- 
produkten, c.q. van andere vergoedingen voor het gebruik van produktiefaktoren en (b) het opstellen van jaarrekeningen bij een gegeven verloop van inkoop- en verkoopprijzen. Deze twee onderwerpen worden telkens afzonderlijk ter sprake gebracht.

\section{Niet-duurzame goederen}

De Jong beschouwt o.a. een voorbeeld waarin een onderneming op een bepaald tijdstip over een voorraad handelsgoederen met een waarde van 400 geldeenheden beschikt. Hiertegenover staan 200 geldeenheden eigen vermogen en 200 geldeenheden vreemd vermogen. De vervangingswaarde wordt geacht tijdens een bepaalde voorraadtermijn te verdubbelen tot 800 geldeenheden, hetzij door een specifieke hetzij door een inflatoire prijswijziging. Aan het eind van de voorraadperiode wordt de totale beschikbare hoeveelheid verkocht en tegelijkertijd vervangen door eenzelfde hoeveelheid tegen de gestegen inkoopprijs.

Om de gedachten verder te bepalen zou men kunnen aannemen, dat de beginvoorraad per 31 december van jaar 0 aanwezig is en dat de verkoop en de vervanging na een normale voorraadtermijn van één jaar, d.w.z. per 31 december van jaar 1 plaatsvinden. Men kan het voorbeeld voorts enigszins uitbreiden door te veronderstellen, dat de vervangingswaarde in de volgende jaren telkens opnieuw wordt verdubbeld, zodat per 31 december van de jaren $2,3,4 \ldots$ een gelijkblijvende hoeveelheid wordt vervangen tegen inkoopbedragen van resp. $1600,3200,6400 \ldots$. geldeenheden.

Zoals De Jong terecht opmerkt, zullen de vermogenskosten door inflatoire prijsstijgingen worden beïnvloed. Laten wij hier aannemen, dat het minimaal verlangde rendement over het eigen vermogen en de te betalen interest over het vreemde vermogen resp. $10 \%$ en $6 \%$ per jaar zijn in geval van louter specifieke prijsveranderingen en resp. $160 \%$ en $120 \%$ in geval van inflatoire prijsveranderingen (met $100 \%$ per jaar). Bij de in de uitgangssituatie bestaande vermogensstructuur $(\mathrm{EV} / \mathrm{VV}=50 / 50)$ zijn de gemiddelde vermogenskosten van de onderneming dan $8 \%$ in geval van specifieke prijsveranderingen en $140 \%$ in geval van inflatie. Tegen deze achtergrond worden achtereenvolgens de kostencalculatie ten behoeve van de besluitvorming en het opstellen van jaarrekeningen besproken.

\section{Kostencalculaties}

De aanwending van een produktiefactor is in het algemeen alleen dan financiëel verantwoord, wanneer de contante waarde van de hieruit voortvloeiende uitgaven en ontvangsten tegen de nominale ofwel de effektieve (d.w.z. de werkelijk geldende) vermogenskosten minstens gelijk aan 0 is. Wat niet-duurzame goederen betreft, betekent dit dat de som van de aanschafprijs en de financieringskosten tijdens de normale voorraadtermijn minstens door de verkoopprijs moet worden gedekt. Men kan met andere woorden zeggen, dat de kostprijs als maatstaf voor de minimaal vereiste opbrengst van een handelsgoed gelijkgesteld moet worden aan:

Aanschafprijs. $(1+$ Vermogenskosten per jaar. Normale voorraadtermijn als fraktie van het jaar) 
Aldus verkrijgt men op grond van het gegeven voorbeeld de volgende berekeningen:

Kostprijs bij verkoop per 31 december

\begin{tabular}{|c|c|c|c|}
\hline Specifieke prijsveranderingen & Jaar 1 & Jaar 2 & Jaar 3 \\
\hline Aanschafprijs & 400 & 800 & 1.600 \\
\hline Financieringskosten à $8 \%$ & $\frac{32}{432}$ & $\begin{array}{r}64 \\
864\end{array}$ & $\frac{128}{1728}$ \\
\hline Inflatie & & & \\
\hline Aanschafprijs & 400 & 800 & 1.600 \\
\hline Financieringskosten à $140 \%$ & $\frac{560}{960}$ & $\frac{1.120}{1.920}$ & $\frac{2.240}{3.840}$ \\
\hline
\end{tabular}

In plaats van de kostprijzen uit de aanschafprijzen af te leiden kan men ook van de vervangingswaarden uitgaan. Daartoe moet men in elk jaar de vervangingswaarde per 31 december verminderen met de waardeverandering tijdens de normale voorraadperiode en vervolgens de financieringskosten over het saldo hiervan bepalen. Dit levert de kostenopstelling bij specifieke prijswijzigingen in het bovenste deel van onderstaande tabel op. In geval van inflatie ligt het meer voor de hand de vervangingswaarde met de reële financieringskosten te verhogen. De reële financieringskosten vindt men door de vervangingswaarde op het moment van verkoop met de reële vermogenskosten te vermenigvuldigen. Zoals bekend is, moeten de reële vermogenskosten in principe als volgt uit de nominale vermogenskosten en de inflatiegraad (de jaarlijkse relatieve prijsstijging) worden afgeleid:

Reële vermogenskosten $=\frac{\text { Nominale vermogenskosten }- \text { Inflatiegraad }}{1+\text { Inflatiegraad }}$

$$
=\frac{1,40-1,00}{1+1,00}=0,20 \text { ofwel } 20 \%
$$

Mits de inflatie niet te hoog is, geldt bij benadering:

Reële vermogenskosten $=$ Nominale vermogenskosten - Inflatiegraad

In de volgende paragraaf zullen wij gemakshalve de tweede formule toepassen. Wegens de door De Jong veronderstelde hoge inflatiegraad - die overigens in sommige landen nog door de werkelijkheid wordt overtroffen - wordt in het onderste deel van de hiernavolgende tabel uitgegaan van de nauwkeurig bepaalde reële vermogenskosten. 
Kostprijs bij verkoop per 31 december

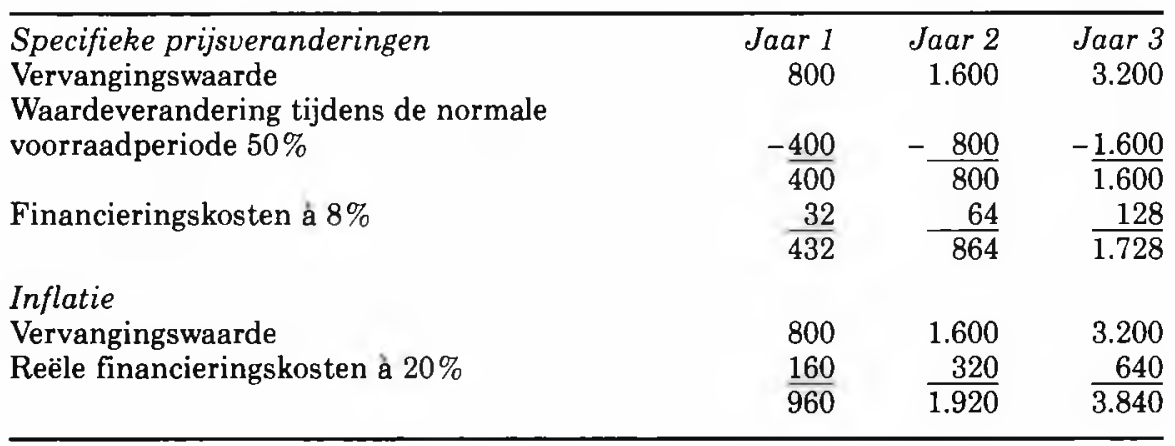

Zoals blijkt levert een kostencalculatie o.b.v. aanschafprijzen in het beschouwde geval precies dezelfde uitkomsten op als een kostencalculatie o.b.v. vervangingswaarden. Dit doet zich echter alleen voor bij de hier gemaakte onrealistische veronderstellingen: met name De Jong's hypothese dat de goederenvoorraad in zijn geheel op éen tijdstip wordt verkocht en vervangen alsmede de door mij hieraan toegevoegde aanname dat de relatieve waardeverandering in de loop van de tijd constant blijft. In de werkelijkheid geven de twee berekeningswijzen doorgaans enigszins verschillende uitkomsten, doordat de goederen met wisselende tussenpozen en in verschillende hoeveelheden worden verhandeld terwijl de inkoopprijzen niet in een constant tempo maar onregelmatig stijgen of dalen.

Er moet in de realiteit dus een keuze tussen de twee calculatiemethoden worden gedaan. Naar mijn mening valt deze keuze ten gunste van de kostencalculatie o.b.v. de vervangingswaarden uit, omdat het kostenverloop hierdoor zo nauw mogelijk op het actuele inkoopprijsverloop aansluit (terwijl de kosten op langere termijn toch de werkelijke inkoopprijzen en financieringskosten dekken). Het is echter wel zo, dat de kostencalculatie o.b.v. vervangingswaarden met betrekking tot niet-duurzame goederen slechts een geringe verbetering ten opzichte van de kostencalculatie o.b.v. aanschafprijzen geeft. In zoverre kan men met De Jong meegaan als hij zegt, dat ook de kostencalculatie o.b.v. aanschafprijzen adequaat is.

\section{Jaarrekeningen}

Doordat de gehele voorraad in De Jong's voorbeeld aan het eind van de beschouwde periode wordt verkocht en vervangen, leveren de verschillende methoden van voorraadwaardering - FIFO-stelsel, LIFO-stelsel, waardering tegen de gemiddelde aanschafprijs en vervangingswaardenstelsel - dezelfde bedragen op. Zou men de voorraadwaardering in het kader van jaarrekeningen verder willen analyseren, dan zou zijn voorbeeld aanzienlijk moeten worden uitgebreid. Met het oog op de beschikbare plaatsruimte en het geduld van de lezer zie ik hiervan te dezer plaatse af. De verschillen tussen jaarrekeningen o.b.v. aanschafprijzen en jaarrekeningen o.b.v. vervangingswaarden kunnen in de volgende paragraaf gemakkelijker met enkele voorbeelden van investeringen in vaste aktiva worden toegelicht. 
In deze paragraaf kan worden volstaan met onderstaande weergave van de jaarrekeningen bij de gegeven (unieke) voorraadwaarden, een constante verhouding tussen het eigen en het vreemde vermogen van 50/50, opname van de jaarlijkse waardestijgingen in de winsten (zie de volgende paragrafen) en jaarlijkse verkoopopbrengsten ter grootte van de hierboven berekende kostprijzen. Het laatste betekent, dat het werkelijke rendement over het eigen vermogen in elk jaar gelijk aan het minimaal verlangde rendement is; voorts betekent dit, dat de expansie in geval van louter specifieke prijswijzigingen ten dele door netto stortingen van de zijde der eigenaren moet worden gefinancierd (A) en dat er in geval van inflatie netto uitkeringen aan de eigenaren kunnen worden gedaan (B). De Jong komt tot dezelfde conclusies. Het zal zonder meer duidelijk zijn hoe de jaarcijfers moeten worden herzien als men uitgaat van hogere of lagere verkoopopbrengsten (dan wel bijvoorbeeld een gewenste verandering van de verhouding tussen het eigen en het vreemde vermogen).

\begin{tabular}{lrrrr}
\hline & Balansen per 31 december & & \\
Debet & Jaar 0 & Jaar 1 & Jaar 2 & Jaar 3 \\
Voorraad & 400 & 800 & 1.600 & 3.200 \\
Credit & & & & \\
Eigen vermogen & 200 & 400 & 800 & 1.600 \\
Vreemd vermogen & 200 & 400 & 800 & 1.600
\end{tabular}

A. Resultatenrekeningen en winstverdelingen i.g.u specifieke prijsveranderingen

Opbrengst

Vervangingswaarde

Interest

Actueel resultaat

Waardestijging

Winst

Vereiste vergroting EV

Storting door eigenaren

\begin{tabular}{|c|c|c|c|}
\hline Jaar 0 & Jaar I & Jaar 2 & Jaar \\
\hline PM & 432 & 864 & 1.72 \\
\hline PM & 800 & 1.600 & 3.20 \\
\hline PM & 12 & 24 & 4 \\
\hline PM & -380 & -760 & -1.52 \\
\hline PM & 400 & 800 & $\underline{1.60}$ \\
\hline PM & 20 & 40 & \\
\hline PM & 200 & 400 & 80 \\
\hline PM & -180 & 360 & \\
\hline
\end{tabular}

B. Resultatenrekeningen en winstverdelingen i.g.u inflatoire prijsveranderingen

Opbrengst

Vervangingswaarde

Interest

Actueel resultaat

Waardestijging

Winst

Vereiste vergroting $\mathrm{EV}$

Uitkering aan eigenaren

$\begin{array}{rrrr}\text { Jaar 0 } & \text { Jaar 1 } & \text { Jaar 2 } & \text { Jaar 3 } \\ \text { PM } & 960 & 1.920 & 3.840 \\ \text { PM } & 800 & 1.600 & 3.200 \\ \text { PM } & \underline{240} & -\frac{480}{160} & -\frac{960}{320} \\ \text { PM } & -80 & -\frac{800}{640} & \underline{1.600} \\ \text { PM } & \underline{400} & \underline{320} \\ \text { PM } & \underline{320} & \underline{400} & \underline{800} \\ \text { PM } & \underline{200} & & \end{array}$

Ofschoon het opstellen van jaarrekeningen met het voorgaande slechts summier is behandeld, wordt éen ding hieruit duidelijk: Evenals kostencalculaties ter beoordeling van verkoopprijzen worden jaarrekeningen in geval van specifieke prijsveranderingen wezenlijk niet anders opgesteld dan in geval van inflatoire prijsveranderingen. De Jong's aanpak, waarbij een 
scherpe scheiding tussen de twee gevallen wordt gemaakt, verdient naar mijn mening dan ook geen navolging.

Om onnodige casuïstiek te vermijden worden in het volgende verder alleen inflatoire prijsveranderingen beschouwd. Het zal zonder meer duidelijk worden, dat de hierover gemaakte opmerkingen mutatis mutandis eveneens voor louter specifieke prijsveranderingen gelden.

\section{Duurzame produktiemiddelen}

Naarmate de gebruiksduur van de door een onderneming gebruikte produktiemiddelen langer is, wijken de uitkomsten van calculaties o.b.v. aanschafprijzen en vervangingswaarden verder van elkaar af. Om de verschillen tussen beide calculatiewijzen zo scherp mogelijk aan te geven, beschouwen wij hier een voorbeeld van investering in een produktiemiddel met een onbeperkte gebruiksduur, i.c. grond. In aansluiting hierop worden de calculaties omtrent duurzame produktiemiddelen met een eindige gebruiksduur - zoals gebouwen, machines en transportmiddelen - besproken.

Stel, dat een beleggingsmaatschappij een stuk land koopt. Bij aankoop is de prijs $f 1.000 .000,-$. Dit bedrag moet op 31 december van een bepaald jaar 0 worden voldaan. Na de aanschaf kan men de grond desgewenst op elk moment tegen de dan geldende marktprijs verkopen.

De beleggingsmaatschappij verhuurt het stuk grond gedurende drie opeenvolgende jaren aan derden. Op basis van het in jaar 0 geldende prijsniveau bedraagt de pacht $f 120.000,-$ per jaar. De pachtsom wordt telkenjare per 31 december voldaan. Aan het eind van jaar 3 wordt de grond verkocht.

De grond wordt juridisch ondergebracht in een afzonderlijke besloten vennootschap met een eigen vermogen van $f 500.000$, - en een vreemd vermogen van $f 500.000,-$ per 31 december van jaar 0 . Uit hoofde van verschillende financiële overwegingen wil de beleggingsmaatschappij ook in de toekomst haar eigendom voor $50 \%$ met eigen en voor $50 \%$ met vreemd vermogen financieren.

De te betalen interest over het vreemde vermogen is $8 \%$ per jaar. Winsten van deelnemingen worden volledig aan de moedermaatschappij uitgekeerd. Er wordt verondersteld, dat alle opnamen en aflossingen van vermogen, interestbetalingen en winstuitkeringen per 31 december plaatsvinden. Belastingen worden buiten beschouwing gelaten.

Ten gevolge van een voortdurende inflatie nemen zowel de marktwaarde van de grond als de pachtsom met $5 \%$ per jaar toe. De grondprijzen per 31 december van de jaren 1,2 en 3 zijn derhalve (afgerond) gelijk aan: $f 1.050 .000,-, f 1.102 .500$, - en $f 1.157 .600,-$. De pachtsommen over de jaren 1,2 en 3 bedragen (eveneens afgerond): $f 126.000,-, f 132.300,-$ en $f 138.900,-$.

Ten behoeve van de kostencalculatie wordt verondersteld, dat het minimaal verlangde rendement over het eigen vermogen $16 \%$ per jaar is. Bij de gegeven verhouding tussen het eigen en het vreemde vermogen van 50/50 en de interest over het vreemde vermogen van $8 \%$ bedragen de gemiddelde 
effectieve vermogenskosten dan $12 \%$ per jaar. De reële vermogenskosten kunnen als verschil tussen de nominale vermogenskosten en de inflatiegraad op $12 \%-5 \%=7 \%$ per jaar worden gesteld.

\section{Kostencalculaties}

De grondkosten o.b.v. de aanschafprijs zouden in alle jaren gelijkgesteld kunnen worden aan: hetzij het produkt van de nominale vermogenskosten en de aanschafprijs ad $0,12 f 1.000 .000,-=f 120.000,-$, hetzij het produkt van de reële vermogenskosten en de aanschafprijs ad $0,07 f 1.000 .000,-=$ $f 70.000,-$.

Beide grootheden hebben echter geen enkele betekenis ter beoordeling van de pachtopbrengsten en wel om twee redenen niet:

- Ten eerste moet aan elke methode van kostencalculatie de eis worden gesteld, dat de door toepassing hiervan berekende bedragen overeenkomstig de aanschafprijzen der produktiefaktoren veranderen; alleen dan kunnen de kosten in opeenvolgende jaren worden vergeleken met de door de inflatie eveneens stijgende opbrengsten. Doordat kostencalculatie o.b.v. de aanschafprijs een constante reeks kostenbedragen oplevert, voldoet deze calculatie niet aan het zojuist geformuleerde criterium.

- Ten tweede moeten kostenbedragen een indicatie van de minimaal vereiste vergoedingen voor de aanwending van produktiefactoren geven. Dit betekent in het algemeen, dat de contante waarde van de jaarkosten tijdens de gebruiksduur van een produktiemiddel plus de contante waarde van een eventuele restwaarde gelijk moet zijn aan de aanschafprijs. Ook aan dit criterium voldoet de kostencalculatie o.b.v. de aanschafprijs niet. Bij stijgende prijzen is de contante waarde van de jaarkosten o.b.v. aanschafprijs en de restwaarde groter dan de aanschafprijs; bij dalende prijzen zou het omgekeerde gelden.

Anders dan in het door De Jong beschouwde geval kunnen de kosten hier dus alleen o.b.v. de vervangingswaarden worden berekend. Daarbij is in het verleden vaak gesuggereerd, dat men de grondkosten in elk jaar gelijk zou moeten stellen aan het produkt van de nominale vermogenskosten en de vervangingswaarde. Inmiddels is men echter zowel in de praktijk als in de theorie tot het inzicht gekomen, dat dan de door De Jong gesignaleerde dubbeltelling plaatsvindt.

Kostenbedragen die aan beide hierboven genoemde eisen voldoen, vindt men - naar thans bekend moge worden verondersteld - door de vervangingswaarde in elk jaar met de reële vermogenskosten te vermenigvuldigen. De desbetreffende bedragen worden hieronder volledigheidshalve weergegeven. (Daarbij zijn de reële vermogenskosten vermenigvuldigd met de vervangingswaarde aan het begin van elk jaar, omdat is verondersteld dat de pacht eenmalig per 31 december wordt ontvangen. Men zou de kosten enigszins moeten herzien als wordt aangenomen dat de pacht geleidelijk gedurende het jaar wordt ontvangen.)

Jaar 1: $f 70.000,-$

Jaar 2: $f 73.500,-$

Jaar 3: $f 77.175,-$ 
Hetzelfde geldt mutatis mutandis voor de calculaties omtrent duurzame produktiemiddelen met een eindige gebruiksduur. Evenmin als in het voorgaande kan een calculatie o.b.v. de aanschafprijs van een dergelijk produktiemiddel een reeks kostenbedragen opleveren, die overeenkomstig het vervangingswaardeverloop stijgt en waarvan de contante waarde gelijk aan de aanschafprijs is. Ook de kosten van duurzame produktiemiddelen met een eindige gebruiksduur kunnen dus alleen uit de vervangingswaarden in de opeenvolgende jaren worden afgeleid.

Dat men hiertoe de vervangingswaarde in elk jaar (c.q. op elk tijdstip) dient te delen door de annuiteitsfactor behorende bij de gegeven gebruiksduur en de reële vermogenskosten, zal ik hier niet opnieuw bewijzen. Ik laat voorts onbesproken, in hoeverre de jaarkosten bij benadering ook gelijkgesteld kunnen worden aan de som van de afschrijvingen o.b.v. de vervangingswaarden en de financieringskosten als produkt van de reële vermogenskosten en de helft van de vervangingswaarde in een jaar.

\section{Jaarrekeningen}

De jaarrekeningen volgens het aanschafprijsstelsel vertonen onder de gemaakte veronderstellingen het volgende beeld. Zoals blijkt, blijft de vermogensstructuur in dit geval tijdens de jaren 1,2 en 3 ongewijzigd. De waardestijgingen van resp. $f 50.000,-$ en $f 52.000,-$ in de jaren 1 en 2 worden niet in de balansen verwerkt noch als bestanddeel van de winsten over deze jaren beschouwd. Pas na de verkoop aan het eind van jaar 3 wordt de totale waardestijging van $f 50.000,-+f 52.500,-+f 55.100,-=$ $f 157.600$, - in de winstberekening opgenomen en als dividend uitgekeerd. Het bedrag op de debetzijde van de balans representeert aan het eind van de jaren 0,1 en 2 de boekwaarde van de grond en aan het eind van jaar 3 het dan beschikbare kasgeld.

Balansen per 31 december ( $\times 1000$ gld)

\begin{tabular}{|c|c|c|c|c|}
\hline $\begin{array}{l}\text { Debet } \\
\text { Grond/Kas }\end{array}$ & $\begin{array}{r}\text { Jaar } 0 \\
1000\end{array}$ & $\begin{array}{r}\text { Jaar } 1 \\
1000\end{array}$ & $\begin{array}{r}\text { Jaar } 2 \\
1000\end{array}$ & $\begin{array}{r}\text { Jaar } 3 \\
1000\end{array}$ \\
\hline $\begin{array}{l}\text { Credit } \\
\text { Eigen vermogen } \\
\text { Vreemd vermogen }\end{array}$ & $\begin{array}{r}500 \\
500 \\
1000\end{array}$ & $\begin{array}{r}500 \\
500 \\
1000\end{array}$ & $\begin{array}{r}500 \\
500 \\
1000\end{array}$ & $\begin{array}{r}500 \\
\frac{500}{1000}\end{array}$ \\
\hline
\end{tabular}

Resultatenrekeningen en winstverdelingen ( $\times 1000$ gld)

\begin{tabular}{lrrrr}
\hline & Jaar 0 & Jaar 1 & Jaar 2 & Jaar 3 \\
Pacht & - & 126 & 132,2 & 138,9 \\
Verkoopresultaat & - & - & - & 157,6 \\
Interest & - & $\frac{40}{86}$ & $\frac{40}{92,3}$ & $\frac{40}{256,5}$ \\
Winst & - & - & - & - \\
Reservering & - & - & - & \\
Dividend & - & & & \\
\hline
\end{tabular}

Bij toepassing van elke variant van het vervangingswaardestelsel worden de balanswaarden gelijkgesteld aan de marktwaarden van de grond. Zoals 
bekend is, heeft men daaraan oorspronkelijk vaak de opvatting verbonden dat de respectievelijke boekwaardeverhogingen buiten de verlies- en winstrekeningen zouden moeten worden gehouden. Deze herwaarderingen zouden in deze gedachtengang rechtstreeks ten gunste van het eigen vermogen - onder de naam herwaarderingsreserve - moeten worden gebracht.

Onder de gemaakte veronderstellingen levert deze methode onderstaande jaarrekeningen op. Het enige verschil met de jaarrekeningen op basis van de aanschafprijs is, dat de balanswaarde van de grond en het eigen vermogen geleidelijk worden vergroot. De omvang van het vreemde vermogen, de winsten en de dividenduitkeringen in de jaren 1 en 2 blijven gelijk aan de eerder vermelde bedragen. Bij verkoop van de grond aan het eind van jaar 3 komt de herwaarderingsreserve te vervallen. De totale waardestijging van de grond in de drie jaren ad $f 157.600$,- wordt op dat moment als een bestanddeel van de winst beschouwd. Bijgevolg blijft ook het dividend over jaar 3 onveranderd.

Balansen per 31 december ( $\times 1000$ gld)

\begin{tabular}{lrrrr}
\hline $\begin{array}{l}\text { Debet } \\
\text { Grond/Kas }\end{array}$ & Jaar O & Jaar 1 & Jaar 2 & Jaar 3 \\
Credit & 1000 & 1050 & 1102,5 & 1000 \\
Eigen vermogen & & & & \\
Vreemd vermogen & 500 & 550 & 602,5 & 500 \\
& $\underline{500}$ & $\frac{500}{1050}$ & $\frac{500}{1102,5}$ & $\frac{500}{1000}$ \\
\hline
\end{tabular}

Resultatenrekeningen en winstverdelingen ( $\times 1000$ gld $)$

\begin{tabular}{|c|c|c|c|c|}
\hline & Jaar 0 & Jaar 1 & Jaar 2 & Jaar 3 \\
\hline Pacht & - & 126 & 132,2 & 138,9 \\
\hline Vrijgev. Herw. res. & - & - & - & 157,6 \\
\hline Interest & - & 40 & 40 & 40 \\
\hline Winst & - & 86 & $\overline{92,2}$ & $\overline{256,5}$ \\
\hline Reservering & - & - & - & - \\
\hline Dividend & - & 86 & 92,2 & $\overline{256,5}$ \\
\hline
\end{tabular}

In plaats van de hierboven geschetste variant van het vervangingswaardestelsel toe te passen kan men de herwaarderingen als positieve bestanddelen van de winsten over de desbetreffende jaren beschouwen. Dit maakt het mogelijk de vermogensstructuur in overeenstemming met de algemene ondernemingsdoelstellingen op 50/50 te handhaven. De respectievelijke jaarrekeningen vertonen in dit geval het volgende beeld. Doordat het vreemde vermogen hierin relatief evenveel stijgt als de waarde van de grond, neemt de te betalen interest geleidelijk toe. De reserveringen in de jaren 1 en 2 zijn gelijk aan de wegens de waardestijging van de grond vereiste vergrotingen van het eigen vermogen. Het gedeelte van de winst dat niet voor de financiering van de deelneming benodigd is, wordt in de vorm van dividend aan de moedermaatschappij uitgekeerd. Aangezien de optimale vermogensstructuur nu voortdurend wordt gehandhaafd, zijn de dividenden in de 
jaren 1 en 2 hoger dan in de eerder behandelde gevallen; dienovereenkomstig is het dividend in jaar 3 bij de eindafrekening lager.

Balansen per 31 december ( $\times 1000$ gld)

\begin{tabular}{|c|c|c|c|c|}
\hline $\begin{array}{l}\text { Debet } \\
\text { Grond/Kas }\end{array}$ & $\begin{array}{r}\text { Jaar } 0 \\
1000\end{array}$ & $\begin{array}{r}\text { Jaar } 1 \\
1050\end{array}$ & $\begin{array}{l}\text { Jaar } 2 \\
1102,5\end{array}$ & $\begin{array}{r}\text { Jaar } 3 \\
1000\end{array}$ \\
\hline $\begin{array}{l}\text { Credit } \\
\text { Eigen vermogen } \\
\text { Vreemd vermogen }\end{array}$ & $\begin{array}{r}500 \\
500 \\
1000\end{array}$ & $\begin{array}{r}525 \\
525 \\
1050\end{array}$ & $\begin{array}{r}551,3 \\
551,2 \\
1102,5\end{array}$ & $\begin{array}{r}500 \\
500 \\
1000\end{array}$ \\
\hline
\end{tabular}

Resultatenrekeningen en winstverdelingen ( $\times 1000$ gld)

\begin{tabular}{|c|c|c|c|c|}
\hline & Jaar 0 & Jaar 1 & Jaar 2 & Jaar 3 \\
\hline Pacht & - & 126 & 132,5 & 138,9 \\
\hline Herwaardering & - & 50 & 52,5 & 55,1 \\
\hline Interest & - & 40 & 42 & 44,1 \\
\hline Winst & - & $\overline{136}$ & $\overline{142,7}$ & 149,9 \\
\hline Reservering & - & 25 & 26,3 & $-51,3$ \\
\hline Dividend & - & 111 & $\overline{116,4}$ & $\overline{201,2}$ \\
\hline
\end{tabular}

Naar mijn oordeel leidt alleen de tweede behandelde variant van het vervangingswaardestelsel tot zinvolle uitkomsten. Er zijn immers geen redenen waarom men het eigen vermogen telkenjare met de totale herwaardering zou moeten verhogen en dus het vreemde vermogen ongewijzigd zou moeten laten; in plaats van deze starre financieringsregel volgens de oorspronkelijke variant van het vervangingswaardestelsel toe te passen kan men beter de herwaarderingen eerst volledig in de winstberekening opnemen en vervolgens de reserveringen in het kader van de financiële planning als geheel bepalen. De Jong blijkt dit standpunt te delen, getuige o.a. het feit dat hij in zijn voorbeelden uitgaat van een gelijkblijvende vermogensstructuur.

Vergelijkt men de jaarrekeningen o.b.v. de aanschafprijzen met de tweede reeks jaarrekeningen o.b.v. de vervangingswaarden, dan verschaft toepassing van het vervangingswaardestelsel naar mijn inzicht zuiverder informatie dan toepassing van het aanschafprijsstelsel. Op dit punt ben ik het dus weer niet eens met De Jong's opvatting, dat ook een calculatie o.b.v. aanschafprijzen adequaat is.

Men komt tot dezelfde conclusies als men de verschillende jaarrekeningen bij investeringen in produktiemiddelen met een eindige gebruiksduur met elkaar vergelijkt. Om herhalingen te vermijden zal ik in dit artikel geen voorbeelden hiervan geven. De algemene kenmerken van de twee waarderings- en winstbepalingsmethoden kunnen als volgt worden samengevat:

Balansen: Balanswaarden o.b.v. aanschafprijzen zijn in geval van waardestijgingen in het algemeen lager dan balanswaarden o.b.v. vervangingswaarden. De verschillen zijn echter geringer naarmate de gebruiksduur korter is. Zoals met het gegeven voorbeeld is geilllustreerd, blijven de balanswaar- 
den o.b.v. aanschafprijzen bij een onbeperkte gebruiksduur der produktiemiddelen steeds gelijk terwijl de balanswaarden o.b.v. vervangingswaarden overeenkomstig de algemene prijsstijging toenemen. Bij een eindige gebruiksduur stijgen beide reeksen balanswaarden. De reden hiervan is vanzelfsprekend dat de twee soorten boekwaarden per produktiemiddel alleen tijdens de gebruiksduur van elkaar kunnen afwijken; bij elke waarderingsmethode daalt de boekwaarde van het oorspronkelijke investeringsbedrag tot nihil (of eventueel de restwaarde) aan het eind van de gebruiksduur.

Teneinde een principiële keuze tussen de twee waarderingsmethoden te maken, kan men opmerken dat boekwaarden ten behoeve van de financieringsplanning door het eigen bedrijf en de beoordeling van de financiële positie van de onderneming door derden een indicatie moeten geven van de financiële resultaten die in de toekomst met de beschikbare produktiemiddelen kunnen worden gerealiseerd. Alleen in dit geval vormt debettelling van de balans een globale maatstaf voor de opbrengstpotentie van de onderneming. Het vreemde vermogen vormt dan de aanspraak die door derden op deze opbrengstpotentie wordt gemaakt; het eigen vermogen geeft bij benadering aan welk bedrag aan de eigenaren zal toevallen. Bijgevolg kan met uit de debettelling van de balans en de bekende overwegingen omtrent de toelaatbare, c.q. optimale verhouding tussen het eigen en het vreemde vermogen afleiden, hoeveel vreemd vermogen in feite ter financiering van de investeringen kan worden aangetrokken.

Aanvaardt men deze algemene waarderingsregel, dan moet het boekwaardeverloop van elk produktiemiddel zo goed mogelijk worden afgestemd op de hiermee in de loop van de tijd te realiseren exploitatieresultaten. Dit betekent o.a. dat slijtende produktiemiddelen met stijgende onderhoudskosten tijdens hun gebruiksduur met dalende bedragen moeten worden afgeschreven (zodanig dat de som van de onderhoudskosten en de afschrijvingen in alle jaren ongeveer gelijk is). Het betekent ook, dat waardering o.b.v. vervangingswaarden in principe de voorkeur verdient boven waardering o.b.v. aanschafprijzen. Als immers de vervangingswaarden van produktiemiddelen stijgen, ligt het voor de hand dat de opbrengsten van de hiermee voort te brengen eindprodukten eveneens een stijgende tendentie vertonen. In geval van prijsstijgingen zouden de boekwaarden van produktiemiddelen met een beperkte gebruiksduur dus met stijgende bedragen per jaar moeten worden verlaagd. Deze uitkomsten worden wel verkregen in geval van waardering o.b.v. vervangingswaarden en niet in geval van waardering o.b.v. aanschafprijzen.

Resultatenrekeningen en winstverdelingen: Ook de winsten en dividenden volgens jaarrekening en o.b.v. aanschafprijzen en vervangingswaarden (met opname van de volledige herwaardering in de winstberekening) wijken minder van elkaar af, naarmate de gebruiksduur der produktiemiddelen korter is.

$\mathrm{Bij}$ een eindige gebruiksduur verschaffen de resultatenrekeningen o.b.v. vervangingswaarden in zoverre extra informatie, dat onderscheid kan worden gemaakt tussen het bedrijfsresultaat o.b.v. actuele waarden (het verschil tussen het jaarlijkse exploitatiesaldo en de afschrijvingen) en het totale bedrijfsresultaat (waarin mede de herwaarderingen worden opgenomen). 
Daar komt bij dat men het totale bedrijfsresultaat van een 'going concern' bij toepassing van het vervangingswaardestelsel in geval van inflatie steeds in twee componenten kan splitsen:

- een inflatiecorrectie op het eigen vermogen, gelijk aan de inflatiefactor maal het eigen vermogen aan het begin van het jaar en

- een reële winst of met andere woorden een reële beloning voor het beschikbaar stellen van eigen vermogen, zijnde het verschil tussen de winst en de inflatiecorrectie op het eigen vermogen. ${ }^{6}$

Men kan de stelling verdedigen, dat de inflatiecorrectie op het eigen vermogen een 'schijnwinst' is die geheel aan de eigenaren van de onderneming toekomt en waarvan andere winstgerechtigden - met name de fiscus - geen deel voor zich zouden mogen opeisen. Hoewel het er niet naar uitziet dat deze visie binnenkort in de wetgeving tot uitdrukking zal worden gebracht, verschaft het bepalen van de inflatiecorrectie op het eigen vermogen en de reële winst in ieder geval zinvolle additionele informatie. Deze berekening sluit logisch aan op een winstberekening o.b.v. vervangingswaarden en minder op een winstberekening o.b.v. aanschafprijzen.

\section{Eindconclusie}

Zoals De Jong nog eens heeft beklemtoond, moeten dubbeltellingen in calculaties o.b.v. vervangingswaarden worden vermeden. Het is echter in het algemeen wel noodzakelijk financiële calculaties op vervangingswaarden te baseren. Calculaties o.b.v. aanschafprijzen leveren slechts in enkele bijzondere gevallen dezelfde uitkomsten op; normaliter verschaffen deze calculaties onzuivere informatie.

\section{Noten}

1 S.E. de Jong, Vervangingswaarde en dubbeltellingen, MAB, januari 1984.

2 I. van der Zijpp, Kosten en jaarrekeningen in geval van veranderende vervangingswaarden, $M A B$, november 1981. Voorts o.a.: Waardering en afschrijving van vaste activa, Bedrijfskunde, 1979, nrs 1 en 2; Administratie en Bedrïfseconomische Analyse, $H$ E. Stenfert Kroese b.u, Leiden - Antwerpen, 1982 hoofdstuk 8; Herwaarderingen in jaarrekeningen, Maandschrift voor bedrijfsadministratie en -organisatie, februari 1982; Herwaarderingen in kostencalculaties, Maandblad voor bedrijfsadministratie en -organisatie, maart 1982.

3 De Jong, t.a.p., blz. 6

4 De Jong, t.a.p., blz. 8

5 De Jong, t.a.p., blz. 13

6 In het voorbeeld van deze paragraaf zijn de inflatiecorrecties op het eigen vermogen in de jaren 1 en 2 resp. gelijk aan $f 25.000$,- en $f 26.250,-$. De reële winsten bedragen in deze jaren derhalve $f 111.000,-$ en $f$ 116.350.-. Zoals blijkt, zijn de inflatiecorrecties op het eigen vermogen gelijk aan de respectievelijke reserveringen terwijl de reële winsten met de dividenduitkeringen overeenkomen. Dit vloeit voort uit de veronderstelling dat zowel de kwantitatieve omvang van de vaste aktiva als de verhouding tussen het eigen en het ureemde vermogen onveranderd worden gelaten. Een zelfde beeld verkrijgt men als de totale waardeverandering van de aan het begin van een jaar beschikbare produktiemiddelen met een eindige gebruiksduur gelijk is aan de totale investering in nieuwe produktiemiddelen. In het algemeen gelden de hier bestaande gelijkheden vanzelfsprekend niet. 